Article

\title{
Do Ownership Ties Increase the Optimistic Bias of Analysts' Earnings Estimates? Evidence from Corporate Financing in the Korean Market
}

\author{
Chune Young Chung ${ }^{1, *}$, Euisup Lee ${ }^{2}$ and Chang-Gyun Park ${ }^{3}$ \\ 1 School of Business Administration, College of Business and Economics, Chung-Ang University, \\ 84 Heukseok-ro, Dongjak-gu, Seoul 06974, Korea \\ 2 Merrill Lynch International LLC, 84-1 Taepyung Road Chung-Gu Seoul Finance Center, Seoul 04520, Korea; \\ euisup.lee@gmail.com \\ 3 Korea Capital Market Institute, 143 Uisadang-daero, Yeongdeungpo-gu, Seoul 07332, Korea; cp19@kcmi.re.kr \\ * Correspondence: bizfinance@cau.ac.kr
}

Received: 26 March 2020; Accepted: 3 June 2020; Published: 7 June 2020

check for updates

\begin{abstract}
Previous studies argue that analysts provide optimistic estimates for corporations with which their brokerage houses have a business relationship. In this study, we investigate whether brokers with ownership ties issue optimistic estimates when their affiliates need support, as when raising debt or issuing equity. We find that Chaebol-owned brokerage houses provide optimistic earnings estimates for their affiliates relative to those provided by other brokers, especially before debt financing. However, we do not observe this relationship in the case of equity financing. These results imply that analysts with ties to corporations expect earnings management to occur around seasoned equity financing and, thus, consider the risks to their reputations. Finally, our results show that brokerage houses with ownership ties are not significantly more accurate than other brokerage houses are.
\end{abstract}

Keywords: conflict of interest; analyst forecast error; Chaebol-affiliated analyst

\section{Introduction}

We examine the effect of ownership relationships between corporations and brokerage houses on analysts' estimates. Numerous prior studies have found that analysts tend to issue optimistic earnings estimates and investment opinions for firms with which their brokerage houses have business relationships (e.g., investment banks) [1,2]. However, fewer studies have examined the effects of ownership ties on analysts' earnings estimates. Korea has a unique corporate ownership structure called a Chaebol, under which many corporations have stakes in one another. Some Korean Chaebols even own sizeable stakes in brokerage houses. These Chaebol-owned brokerage firms provide earnings estimates for their affiliates, with which they have direct or indirect ownership ties. We primarily investigate whether these analysts remain objective and independent when issuing earnings estimates for firms with which their brokerage houses have ownership relationships. In addition, we investigate whether such analysts become more optimistic when their affiliates need support, as when attempting to raise funds, for example.

Choi et al. [3] document that Korea has 61 Chaebol enterprises, including Samsung, Hyundai, LG, and Lotte, and 1606 subsidiaries as of April 2015. According to the Korea Exchange (KRX), the total market capitalization of Chaebols exceeds 2258 trillion Korean won, which is a rather sizable share of the entire market capitalization of KRX-indexed corporations. For decades, leading Korean companies have received substantial governmental benefits and subsidies as part of Korea's economic growth strategy. These leading companies now dominate Korea's corporate environment. The family 
members who control Chaebols are likely to exercise considerable authority in corporate management and engage in selfish behavior that may damage outside shareholders' interests. The managers and dependent board members of these firms are vulnerable to poor (voluntary) corporate disclosure and infringements of accounting regulations and other laws, adding to these firms' information asymmetry.

This study is motivated by the existing literature. Park and Youn [4] document that optimistic estimates are more frequent if a special relationship, such as cross-ownership or ownership ties, exists. However, they find no statistically significant relationship between optimistic forecast biases and ownership ties, concluding that analysts' motivation to protect their reputations (by providing accurate information) is greater than any benefit from issuing optimistic estimates. Despite this finding, it is worth examining whether analysts' forecasts become more optimistic when ownership ties exist. Additionally, Li et al. [5] show that analysts engaged in investment banking provide optimistic forecasts when management needs their support. Although their study focuses on business relationships, analysts may provide optimistic estimates when corporations need their help. Based on these studies, we first examine whether optimistic bias exists when ownership ties exist. Second, we investigate whether analysts with ownership ties provide overly optimistic estimates during special periods, which we define as those when corporations announce debt or equity financing. Debt financing includes issuances of corporate bonds and commercial bills, and equity financing refers to new share issuances. In contrast to previous studies, we find that analysts with ownership ties tend to make optimistic estimates in all periods. Furthermore, we suggest that this optimism should be attributed to reasons other than investment banking, such as the movement of top managers between brokerage houses and the companies they cover (i.e., analysts' career concerns). This finding indicates that corporate governance issues within Korean Chaebols may affect the estimates of analysts with whom they have ownership ties.

The findings of this study are as follows: we find that Chaebol-owned brokerage houses provide optimistic earnings estimates for their affiliates; we also find that this optimism is amplified during certain special periods, such as debt financing periods. However, even brokerage houses with ownership ties resist presenting optimistic estimates when their affiliates are about to announce equity financing, which usually signals a negative future operational environment, most likely because the analysts consider the risk to their reputations. However, the estimates of non-tied brokers tend to be more pessimistic during special periods, indicating that they interpret all external funding activities as negative signals for future earnings. Hence, analysts are likely to try to issue more accurate estimates when negative operations are expected, owing to the reputational risk, because investors' attention increases during such periods. Jackson [6] and Fang and Yasuda [7] show that analysts try to avoid misleading investors because announcing earnings estimates is associated with their reputations. We also find that the accuracy levels of brokerage houses with ownership ties are not statistically different from those of other brokerage houses. This result suggests that brokerage houses with ownership ties do not have superior information to that of their non-affiliated counterparts. Alternatively, they may have superior information, but may also be less accurate owing to their optimism.

This study makes three main contributions to the literature. First, whereas previous studies focus on the influence of business relationships, such as investment banking relationships [1,2,5,8], we focus on ownership ties. Second, we review all 3422 filings announced by Korean Chaebols between 2009 and 2013 to identify special periods, including periods of debt financing, equity financing, and other stake transactions, which no previous study has done. Lastly, we show that analysts expect firms to manage their earnings around equity financing periods. Furthermore, investors pay greater attention to analysts' estimates during such periods, meaning that analysts with ownership ties experience greater risk to their reputations during equity financing periods.

The remainder of the paper is organized as follows: Section 2 introduces the related literature, Section 3 develops our hypotheses, Section 4 describes the data and the sample, Section 5 presents the empirical results, and Section 6 concludes. 


\section{Literature Review}

\subsection{Optimistic Earnings Estimates}

Many studies argue that analysts' earnings forecasts and stock recommendations generate excess returns [9-11], suggesting that analysts and other stock market participants may have asymmetric information or that analysts have superior predictive ability. If analysts have superior ability such that following their stock recommendations creates value, they should remain objective when issuing recommendations to avoid misleading investors. Because of this gap/complexity in understanding the key factors behind analysts' forecasts, numerous studies investigate the factors that influence analysts' estimates and investment opinions as well as regulations that can improve market efficiency.

The most representative topic in this literature is that of optimistic earnings forecasts. These are recommendations made by sell-side analysts with the intention of improving their relationships with management or generating higher commission income [12-16]. Other studies [1,2,5,8] argue that analysts who work for brokerage houses tend to give optimistic earnings estimates and investment opinions for corporations if they have related investment banking business. Furthermore, Jegadeesh et al. [17], Eccles and Crane [18], and Jackson [6] suggest that analysts' compensation is linked to their ability to support investment banking and generate trading value. As a result, they issue optimistic estimates to build good relationships with management. Although most previous studies focus on business relationships, other special relationships between analysts and corporations may also affect analysts' estimates.

Lin and McNichols [19] show that investors respond similarly to "strong buy" and "buy" recommendations from lead underwriters and unaffiliated brokers. However, the three-day returns following lead underwriters' "hold" recommendations are significantly more negative than those following recommendations of unaffiliated brokers. This finding suggests that investors consider lead analysts more likely to recommend "holding" when "selling" is warranted. If investors differentiate between underwriters' and unaffiliated brokers' recommendations, underwriting analysts may worry less about their reputational risk. However, Jackson [6] and Fang and Yasuda [7] suggest that reputational concerns drive analysts to avoid misleading investors because earnings estimates are a repeated game. Meng [20] further suggests that misaligned and aligned analysts both want to develop good reputations for future business, and, thus, both have an incentive to communicate truthfully. Chen et al. [21] show that investors trust analysts' future recommendations based on their past forecast errors (FE), suggesting that reputation is important for investor recognition. Groysberg et al. [22] find that analyst compensation is positively related to recognition by buy-side clients and that analyst turnover is related to estimation accuracy. Jackson [6] shows that optimistic analysts generate more trades and have good reputations but that accurate analysts develop good reputations eventually. Thus, analysts face an internal conflict between making accurate estimates that improve their long-term reputations and providing optimistic forecasts that improve their trading and short-term reputations.

\subsection{Earnings Estimates and Firm Events}

Previous studies have also shown that a market's reaction to analysts' recommendations persists only in the short term, suggesting that analysts must issue optimistic recommendations near events to support corporations. Brav and Lehavy [23] show empirically that markets react significantly to short-term analyst information, including target prices, earnings estimates, and recommendations. Barber et al. [9] and Ko et al. [24] also show that following analysts' opinions generates positive returns only in the short term. In particular, based on the Korean market, Kwak and Mo [25] find that group-affiliated analysts issue more accurate and less optimistic earnings forecasts for affiliated firms when the level of information asymmetry is low. Furthermore, using tests of abnormal trading volumes and independent analysts' reactions, Lim and Kim [26] show that investors and independent analysts recognize and discount an optimistic bias in Chaebol-affiliated "buy" recommendations. In contrast, the long-term market returns are more profitable when following affiliated analysts' "buy" 
recommendations rather than independent analysts' recommendations. They argue that investors excessively discount Chaebol-affiliated "buy" recommendations in the short term in the Korean market. Our study further contributes to the related literature by focusing on affiliated analysts' manipulative earnings forecasts around group-affiliated firms' financing, which highly incentivizes their optimistic recommendations.

\section{Hypothesis Development}

We mainly examine whether analysts maintain objectiveness and independence when they issue earnings estimates for firms with which their brokerage houses have ownership relations. Numerous prior studies [2,19] find that analysts tend to issue optimistic earnings estimates and investment opinions if the covered firms have business relationships, such as investment banking relationships, with their brokerage houses. However, the impact of ownership ties on analysts' earnings estimates has not been examined as much, and this study shifts the focus to the impact of ownership ties rather than that of business relationships. Korea has a unique corporate ownership structure called the Chaebol, and many corporations own stakes in one another under this structure. Some Korean Chaebols even own sizeable stakes in brokerage houses, and Chaebol-owned brokerage firms provide earnings estimates for their affiliates with direct or indirect ownership ties. To measure the impact of these ownership ties, we examine whether analysts maintain objectiveness and independence when they issue earnings estimates for firms with which their brokerage houses have ownership relations (Hypothesis 1: Affiliated analysts issue more optimistic forecasts). Then, we expand the analysis to determine whether analysts' estimates change if a special event, such as fundraising activity, occurs (Hypothesis 2: Analysts issue more conservative forecasts during special events). We define the special events that require analysts' support as periods in which corporations announce external fundraising activities.

We also categorize the special events as debt financing, equity financing, and other transactions and examine the combined effects of ownership ties and the type of special event. Presumably, based on pecking order theory, a company's management is likely to prefer internal to external funding if the internal cashflow is sufficient because of its lower funding costs. Companies are also likely to prefer debt financing to equity financing. According to pecking order theory [27], corporations prefer internal to external funding and debt financing to new equity issuances in the case of external financing. Pecking order theory stems from the idea of asymmetric information, implying that a company's management has more information about its prospects than outside investors have. If creditors and equity investors have less information about a corporation, they will ask for higher returns to compensate for the risk of asymmetric information. In addition to these higher returns, corporations must also consider the agency costs of issuing bonds or equity (e.g., brokerage fees, taxes, roadshow costs, and so on). Considering the higher costs of external funding, it is natural for a company's management to prefer internal financing if it is possible. In the case of insufficient internal funding capability, however, the management must seek external funding sources. In that case, it prefers debt financing to equity financing because of the lower funding costs owing to the tax shielding effect of debt financing. After debt has reached a risky leverage level, managers choose to issue new shares as a last resort. Additionally, analysts consider their reputation risk more during special event periods because investors pay more attention to companies that are about to announce fundraising activities and because a company's management is likely to provide more information to investors during a special event period.

We investigate whether special events affect the estimates of analysts with and without ownership ties differently (Hypothesis 3: Affiliated analysts issue more optimistic forecasts during special event periods). Furthermore, we examine whether analysts with ownership ties behave differently in the case of different fundraising activities. Specifically, we investigate how analysts with ownership ties react when affiliated firms need their support but the analysts still need to consider their reputations (Hypothesis 4: Affiliated analysts issue more conservative forecasts if the earnings outlook is gloomier 
(i.e., the case of equity fundraising)). In general, debt financing is a relatively more frequent activity for a corporation, but equity financing is not typically used by listed companies unless they have significant difficulties with debt financing. We hypothesize that even analysts with ownership ties must consider their reputational risks in the case of equity financing.

According to pecking order theory [27], corporations prefer internal to external funding if internal cashflows are sufficient owing to the lower funding costs. However, if forced to consider external funding, they prefer debt financing to equity financing. Pecking order theory stems from asymmetric information because managers have more information about their corporations' prospects than outside investors do. If creditors and equity investors have less information about a corporation, they ask for higher returns to compensate for the asymmetric information risk. Furthermore, corporations must also consider agency costs when issuing bonds or equity (e.g., brokerage fees, taxes, roadshow costs, etc.). Considering the higher costs of external funding, managers naturally prefer to use internal financing if possible. If internal funding is insufficient, they must seek external funding. Then, they prefer debt financing to equity financing because debt financing is cheaper owing to its tax-shielding effect. When debt financing reaches a risky leverage level, managers decide to issue new shares as a last resort. Furthermore, Rangan [28] and Shivakumar [29] find that firms engage in earnings management around seasoned equity offerings, indicating that managers try to boost their earnings before rights offerings. Shivakumar [29] also shows that investors acknowledge earnings management before equity offerings and rationally undo its effects. Analysts tend to be optimistic because optimism is better for their careers during normal periods [30]. However, this relationship does not hold if their optimism leads to incorrect estimates, which tend to be noted by investors. Thus, analysts are more likely to consider the risk to their reputations during equity financing periods because investors focus more on corporations that try to manage their earnings upward during such periods.

\section{Research Design and Sample}

\subsection{Research Design}

\subsubsection{Forecast Error and Absolute Forecast Error}

We focus on whether the estimates of Chaebol-related brokerage houses are especially optimistic. However, we also investigate whether the earnings estimates of analysts with ownership ties are more accurate than those of their peers. The first investigation examines the FE, which indicates whether the estimated net profit is more optimistic or pessimistic than the actual net profit (Equation (1)). The second investigation examines the absolute forecast error (AFE), which simply shows the difference between the estimated and actual net profit regardless of the direction of the gap (Equation (2)). Thus, in this study, we analyze the FE, defined below, using two methods.

$$
\begin{gathered}
F E_{i j t u}=\frac{N P F_{i j t u a}-N P A_{j u}}{N P A_{j u}} \\
A F E_{i j t u}=\left|\frac{N P F_{i j t u a}-N P A_{j u}}{N P A_{j u}}\right|,
\end{gathered}
$$

where, for a report by analyst $j$ published at time $t$ for company $i$ in fiscal year $u$,

$F E_{i j t u}=$ Forecast error

$A F E_{i j t u}=$ Absolute forecast error

$N P F_{i j t u a}=$ Forecasted net profit for the controlling stake

$N P A_{j u}=$ Actual net profit for the controlling stake.

Here, $N P F_{i j t u}$ is an estimate of company $j$ 's net income for a controlling stake at future time $u$ delivered by analyst $i$ at time $t$, and $N P A_{j u}$ is an estimate of $j$ 's actual announced net income at time $u$. Thus, $F E_{i j t u}$ is the ratio given in actual terms by calculating the difference between the predicted 
estimate and the actual figure at time $t$, from coverage firm $j$ 's point of view, using the net income at time $u$ forecasted by analyst $i$. This ratio uses signs to determine whether the analyst's estimate is positive or negative rather than using the absolute value in the calculation.

Then, $A F E_{i j t u}$ measures the absolute value; any deviations from the actual net income are treated equally. This formula is mainly used when evaluating the accuracy of an analyst's prediction. Equation (1) measures the forecast bias of an analyst's earnings estimate relative to actual earnings. At the same time, Equation (1) determines whether the forecast bias is optimistic or pessimistic. In contrast, Equation (2) measures the accuracy of the earnings forecast regardless of the direction of the bias. Given that performance in year $t$ is announced at the end of March of year $t+1$, the earnings estimates for year $t$ are calculated using data from April in year $t$ to March in year $t+1$. Corporations in Korea must file annual financial statements within three months of their fiscal year end, and most corporations file statements near the deadline. As noted, the end of the fiscal year in Korea is the end of December, although some financial companies choose the end of March as their fiscal year end.

\subsubsection{Control Variables}

In terms of the other explanatory variables, the regression results for the analyst and corporation characteristics have similar statistical significance levels to those found by previous studies. In terms of corporation-related factors, we include market capitalization, beta, stock trading value, book-to-market ratio, and number of covering analysts as explanatory variables. In general, if the market capitalization and stock trading value of a corporation are large, the corporation likely generates more profit for the brokerage firm. As a result, analysts are pressured to issue optimistic earnings forecasts to build good relationships with management $[6,17,18]$. However, counterarguments state that large market capitalizations and transaction values improve the accuracy of analysts' estimates because analysts tend to dedicate more time to larger companies than they do to smaller companies, as more readers refer to research papers and earnings estimates for larger companies. Jackson [6], Fang and Yasuda [7], and Chen et al. [21] suggest that reputation is an important driver of investor recognition. Our FE regression results in Table 5 demonstrate that if a corporation's trading value, market capitalization, and investor interest are high, then analysts' estimates are more conservative (pessimistic), suggesting that analysts care more about reputational risk and do not issue optimistic estimates. Additionally, Lo [31] suggests that analysts' reports are more favorable to small firms than to large firms despite the lower level of investor attention and revenue contribution because following a small corporation might imply that the analyst expects the firm's prospects to be healthy. However, our analysis reveals different results for the trading value of a corporation. Specifically, analysts' accuracy decreases if the trading value of a corporation increases, implying that analysts' conservative attitudes do not improve accuracy. Corporations with high book-to-market ratios tend to be in mature rather than growth stages, and, thus, estimating future earnings should be easier. However, our results indicate decreasing accuracy as the book-to-market ratio increases, although this decrease is milder. Analysts' estimates tend to be pessimistic under a slow growth outlook (i.e., a small negative coefficient on FE). This result is similar to that of Jegadeesh et al. [17], who show empirically that sell-side analysts favorably recommend growth firms, firms with more trading activity, and relatively expensive stocks. If many analysts cover a company, indicating its importance to brokerage firms, it is more likely that additional resources will be dedicated to covering the company. Moreover, the intensified competition among analysts reduces the prediction error. $\mathrm{Yu}$ [32] investigates the effect of the number of analysts on accuracy, finding that a company's earnings management decreases as the number of analysts increases. Our regression results show a similar result that analysts' estimates become more accurate as the number of analysts increases; however, this result is not statistically significant.

In terms of analyst-related variables, we include the number of companies covered, the asset size of the brokerage house, and the time difference. One analyst covering many companies creates a trade-off. Many previous studies argue that accuracy tends to decrease if an analyst covers more firms because he or she may spend less time predicting future earnings owing to a heavy workload 
and complex portfolio [33]. Our findings also show that when the number of companies covered increases, analysts' estimates become less accurate and tend to be optimistic. Brokerage houses with large asset sizes tend to earn higher profits, allowing them to hire highly skilled analysts at higher salaries or to purchase industry data from third parties to make more accurate estimates [10,16,33-35]. However, several recent studies present different results. Oh and Park [36] show that analysts at larger brokerage houses are more pessimistic and that their estimates are less accurate. Presumably, greater homogeneity in information owing to a small market size and easy internet access narrows the gap between large and small brokerage houses. We find that the optimistic bias increases and the accuracy decreases as the asset size of a brokerage house increases, although these results are not statistically significant. The time difference is not linked directly to analyst characteristics, but we include it among these characteristics because analysts can obtain more information as the actual net income release date approaches. Intuitively, earnings estimates are more accurate when analysts can access more information (e.g., updated sales, changes in industry conditions, etc.). Our analysis shows that this intuition is correct because accuracy decreases and optimistic bias increases as the time difference increases.

With regard to the dummy variables, we find a positive coefficient on FE after the Korean International Financial Reporting Standards (K-IFRS) were introduced, implying that analysts' forecasts have been optimistically biased since the K-IFRS adoption. Given unfamiliar accounting rules and a lack of a detailed earnings breakdown, analysts likely need to obtain information from the management and, thus, issue overly optimistic estimates to gain favor with the management [37]. We further find that the Business Survey Index (BSI) influences analyst FE. Here, FE is reduced despite analysts' optimism when better economic conditions result in higher actual earnings. We use the directional change in year-over-year (YoY) net income as a dummy variable that takes a value of one if YoY net income increases and a value of zero otherwise. If a corporation's earnings growth is higher, the optimistic bias will be offset if actual earnings are above expected earnings. These results suggest that an offset effect occurs as analysts' accuracy improves if corporations' earnings are increasing, but that their estimates appear pessimistic, owing to higher actual earnings.

\subsection{Sample Selection}

We gather earnings estimates of local brokerage houses from FnGuide for the period from 2009 to 2013. Then, we exclude observations (1) with unclassified broker names, (2) with FEs over $200 \%$ (to exclude outliers), and (3) from the financial industry owing to its different fiscal year end. This process yields 94,760 observations from 40 local brokerage houses. Tables 1-3 provide descriptive statistics.

Six of the 40 local brokerage houses are categorized as Chaebol-related (ownership-tied): Samsung Securities, Hanwha Securities, Hi Investment and Securities, HMC Securities, SK Securities, and Dongyang (currently Yuanta) Securities. Because we exclude observations from the financial industry, the estimates of brokerage houses with ownership ties to financial companies are not considered even if such ties exist. Those brokerage houses with ownership ties to financial corporations but not to non-financial corporations include Shinhan Securities, NH Securities, Woori Securities, Hana Securities, IBK Securities, Mirae Securities, and Korea Investment and Securities; see Table 2. After obtaining a sufficient sample size and identifying Chaebol-related brokerage houses, we investigate all filings reported by Chaebols from 2009 to 2013 in the Data Analysis, Retrieval, and Transfer System. As such, we capture special periods, which include bond issues, commercial note issues, new share issues, mergers and acquisitions, stake transactions with other affiliates, capital reductions, and warranty exercises. Then, we sort the events into three groups: periods of debt financing, equity financing, and other equity transactions.

We focus primarily on funding and ownership structure-related events because affiliates are likely to need support from a brokerage for such activities. We define earnings estimates 30 days prior to an event as the special period, and we use estimates 60 and 90 days prior to the event for supplementary analyses. We find no clear precedent for using a specific number of days before an event because 
previous studies also use special periods of various lengths. For example, studies that demonstrate the investment gains associated with analysts' opinions investigate these gains over a range of three days to six months after the opinions are issued $[5,9,24,38]$. We define 30 days prior to special period announcements as the event period because previous studies indicate that analysts' recommendations affect investors in the short term $[9,24]$.

Table 1. Descriptive statistics for fiscal years 2009-2013.

\begin{tabular}{|c|c|c|c|c|c|c|}
\hline Year & $\begin{array}{c}\text { Number of } \\
\text { Observations }\end{array}$ & Mean & STD & Q1 & Median & Q3 \\
\hline \multicolumn{7}{|c|}{ Panel A Analyst forecast error(\%) } \\
\hline 2009 & 24,829 & -4.183 & 45.006 & -22.384 & -3.203 & 9.164 \\
\hline 2010 & 25,239 & -1.28 & 42.952 & -19.004 & -3.977 & 11.527 \\
\hline 2011 & 8,426 & 8.251 & 46.063 & -0.598 & 4.838 & 19.897 \\
\hline 2012 & 17,513 & 14.378 & 46.439 & -2.235 & 7.362 & 29.714 \\
\hline 2013 & 18,753 & 12.091 & 53.304 & -2.081 & 7.436 & 30.985 \\
\hline Total & 94,760 & 4.346 & 47.232 & -12.264 & 1.082 & 19.328 \\
\hline \multicolumn{7}{|c|}{ Panel B Analyst absolute forecast error (\%) } \\
\hline 2009 & 24,829 & 28.942 & 34.718 & 5.315 & 15.865 & 41.437 \\
\hline 2010 & 25,239 & 27.348 & 33.144 & 7.158 & 16.105 & 33.158 \\
\hline 2011 & 8,426 & 26.312 & 38.697 & 2.882 & 10.586 & 30.721 \\
\hline 2012 & 17,513 & 30.469 & 37.88 & 5.122 & 15.954 & 39.583 \\
\hline 2013 & 18,753 & 34.492 & 42.432 & 5.063 & 17.413 & 45.561 \\
\hline Total & 94,760 & 29.664 & 37.011 & 5.401 & 15.669 & 38.616 \\
\hline \multicolumn{7}{|c|}{ Panel C Control variables } \\
\hline \multicolumn{2}{|c|}{ Trading value (mn) } & 1043 & 1488 & 0.180 & 0.500 & 1300 \\
\hline \multicolumn{2}{|c|}{ Beta } & 0.939 & 0.417 & 0.643 & 0.972 & 1.231 \\
\hline \multicolumn{2}{|c|}{ Market cap } & $9,533,904$ & $24,885,069$ & $1,100,000$ & $3,500,000$ & $9,200,000$ \\
\hline \multicolumn{2}{|c|}{ Book-to-market } & 1.958 & 0.734 & 0.603 & 2.064 & 3.018 \\
\hline \multicolumn{2}{|c|}{ Company coverage } & 20.707 & 9.137 & 14.000 & 22.000 & 28.000 \\
\hline \multicolumn{2}{|c|}{ Coverage } & 8.593 & 4.077 & 6.000 & 8.000 & 11.000 \\
\hline \multicolumn{2}{|l|}{$\begin{array}{l}\text { BSI (Business } \\
\text { Survey Index) }\end{array}$} & 81.819 & 9.266 & 75.000 & 83.000 & 89.000 \\
\hline
\end{tabular}

Note: The sample includes 94,760 analyst report-year observations.

Additionally, analysts must issue estimates close to events if they want to support their affiliates. However, we also investigate estimates 60 and 90 days prior to events for robustness. Because analysts issue earnings estimates at least once per quarter (in general, they revise their estimates when quarterly results are announced), estimates 60 or 90 days before certain events likely capture most of the revisions prior to the events. Furthermore, brokers with ownership ties are likely to acknowledge events one to two months prior if they have internal information about these events.

Table 2. List of Chaebol-related brokerage houses and their affiliated companies.

\begin{tabular}{cc}
\hline Brokerage House & Affiliated Companies \\
\hline Hanwha & Hanwha, Hanwha Chemical, Hanwha Fine Chemical \\
Hi Securities & Hyundai Heavy Industry, Hyundai Mipo Dockyard \\
HMC Securities & Hyundai Motor, Kia Motor, Hyundai Mobis, Hyundai Wia, Hyundai Glovis \\
& Samsung SDI, Samsung Electronics, Samsung Engineering, SEMCO, \\
Samsung Securities & Samsung Fine Chemical, Samsung Heavy, Samsung Techwin, S-1, \\
& Cheil Communication, Hotel Shilla \\
SK Securities & SK Corp, SK C\&C, SKC, SK Gas, SK Network, SK Telecom, SK Innovation, \\
Dongyang & SK Comms., SK Chemical, SK Hynix \\
& DY Corporation \\
\hline
\end{tabular}

Note: The data cover fiscal years 2009-2013. 
All details are shown in Table 3. A total of 3422 events are captured during the period, 1865 of which are those of Chaebol-related companies.

Table 3. Special periods for the period 2009-2013.

\begin{tabular}{ccc}
\hline (Unit: Number of Events) & $\begin{array}{c}\text { Special Periods } \\
\text { during 2009-2013 }\end{array}$ & $\begin{array}{c}\text { Special Periods during } \\
\text { 2009-2013 for Chaebols }\end{array}$ \\
\hline Debt financing (=Event 1) & $\mathbf{2 8 1 6}$ & $\mathbf{1 6 5 4}$ \\
\hline Bond issue & 2808 & 1654 \\
Note issue & 8 & 0 \\
\hline Equity financing (=Event 2) & $\mathbf{2 7 9}$ & $\mathbf{8 8}$ \\
\hline Rights offering & 266 & 87 \\
Capital reduction & 13 & 1 \\
\hline Other transactions (=Event 3) & $\mathbf{5 6 1}$ & $\mathbf{1 2 3}$ \\
\hline Merger & 91 & 27 \\
Stake transaction & 234 & 94 \\
Exercising warranty & 1 & 1 \\
Net income decline YoY & 235 & $\mathbf{1 8 6 5}$ \\
\hline Total & $\mathbf{3 4 2 2}$ & 1 \\
\hline
\end{tabular}

Note: This table presents the special periods between 2009 and 2013, defined as Events 1, 2, and 3.

\section{Results}

\subsection{Model Specification}

We use a multivariate regression analysis for the empirical model. First, we investigate whether the FE of brokerage houses with ownership ties is statistically different from that of non-tied brokerage houses using a dummy variable. We examine whether analysts who work for brokerage houses with ownership ties issue optimistic estimates across the time horizon. We use dummy variables to indicate the existence of ownership ties between an analyst and a corporation and to indicate whether estimates are issued during special periods. Furthermore, we examine whether the estimates of brokers with ownership ties change during special periods using the interactions between these dummy variables. For ease of interpretation and analytical robustness, we also use a combined dummy variable. The regression equation is given as follows:

$$
F E_{i j t u}=a x_{j t}+\lambda z_{i t}+\delta D u m m y_{i j t}+\varepsilon_{i t j}
$$

where:

Covered company's stock trading value: Log(Trading value)

Covered company's beta: Beta

Covered company's market capitalization: Log(Market cap.)

Book-to-market ratio: Book-to-market

Number of analysts who cover the firm: Company coverage

YoY change in net income: Earnings growth

Remaining days to earnings release vs. the timing for an analyst to issue estimates: Time difference

Number of companies covered: Coverage

Existence of ownership ties: Affiliates

Size of brokerage firm: Log(Broker assets)

Adoption of K-IFRS: IFRS

Ownership ties with corporations: Affiliates

Special period: Event 
In the above formula, $x_{j t}$ reflects the characteristics of corporation $j$ at time $t$ that explain the dependent variable, and $z_{i t}$ is the explanatory variable that describes analyst $i$ and the brokerage house that includes the analyst. For the control variables, we use variables that prior studies find to be relevant. The explanatory variables related to analyst characteristics include the number of companies covered per analyst, the time difference (i.e., the time gap between the day that the analyst's estimate is issued and that of the actual net profit), and the asset size of the brokerage firm. The explanatory variables related to corporation characteristics include the trading value, beta, market capitalization, book-to-market ratio, and number of analysts who cover the company.

Dummy $_{i j t}$ is a dummy variable that describes characteristics of the earnings estimation for corporation $j$ by analyst $i$ at time $t$. A dummy variable is used to indicate whether ownership ties exist (i.e., it takes a value of one if an analyst belongs to a brokerage firm with ownership ties and a value of zero otherwise). We also use dummy variables to indicate special periods (i.e., if analysts' estimates are issued during a special period, the dummy variable takes a value of one). Then, we categorize the special periods into those related to debt financing, equity financing, and other equity-related transactions. To measure the combined effect of ownership ties and special periods, we use the interactions between the dummy variables. (1) If an estimate is issued by an analyst with ownership ties during a special period, all three dummies (i.e., affiliate, event, and affiliate $\times$ event) take a value of one. (2) If an estimate is issued by an analyst with ownership ties during a non-special period, the affiliate dummy takes a value of one, but the event and interaction term dummies (affiliate $\times$ event) both take values of zero. (3) If an estimate is issued by a non-ownership-tied analyst during a special period, the event dummy takes a value of one, but both the affiliate and the affiliate interaction dummies (affiliate $\times$ event) take values of zero. The interaction term dummy is clearly statistically significant for the combined effect of ownership ties and the event period. However, we must estimate the differences between the coefficients to determine whether the combined FE effect indicates an optimistic or pessimistic bias. To clearly illustrate this hypothesis, we perform supplementary analyses. Instead of interaction terms, we create combined dummy variables that reflect ownership ties and special periods, as follows: (1) estimates by analysts with ownership ties during special periods, (2) estimates by analysts with ownership ties during non-special periods, (3) estimates by analysts without ownership ties during special periods, and (4) estimates by analysts without ownership ties during non-special periods. Then, we conduct a Wald test to examine the differences in the coefficients of each dummy variable. We also use a dummy variable for the change in YoY net income (equal to one if YoY net income increases and zero otherwise). These variables are summarized in Table 4 and specifically defined in Table A1 in Appendix A.

Table 4. Explanatory variables for the main regression model.

\begin{tabular}{ccc}
\hline$x_{j t}$ & $z_{i t}$ & Dummy $_{i j t}$ \\
\hline Book-to-market ratio & Coverage & Affiliate \\
Beta & Time difference & Event \\
Market cap & Asset size of brokers & IFRS \\
Trading value & & Net income growth \\
Number of analysts & & \\
BSI & &
\end{tabular}

Note: Here, $\chi_{j t}$ represents firm (j)-specific control variables at time $t$, and $z_{i t}$ represents analyst (i)-specific control variables at time $t$. Dummy $y_{i j t}$ represents the dummy variables affiliate, International Financial Reporting Standards (IFRS), and net income growth, which take values of one if an analyst's brokerage house and the covered companies are affiliated, if the company reports financial statements under IFRS, and if the company's net income to a controlling stake grows, respectively, and take values of zero otherwise.

\subsection{Hypothesis 1}

Hypothesis 1 states that the earnings estimates of brokers with ownership ties are optimistically biased. 
Using a multivariable regression with dummy variables, we find that the earnings estimates of brokerage houses with ownership ties are statistically more optimistic than those of brokerage houses without ownership ties at the $1 \%$ statistical significance level, as shown in Tables 5 and 6 . Notably, we observe optimism over all time horizons, from 30 days to 90 days before an event, implying that brokers with ownership ties maintain their optimistic bias almost always because, in general, sell-side analysts issue earnings estimates at least once per quarter. However, it is difficult to clearly specify the reason for this optimism because a few different reasons are plausible. Korean Chaebols exchange managers among their affiliates, which means that corporate managers may be relocated to brokerage companies in the future. Furthermore, the managers of corporations may be friends with the managers of brokerage houses, making it difficult for analysts with ownership ties to issue unfavorable estimates or recommendations. Moreover, affiliates may have both ownership and investment banking ties. Yeonhap Daily reported in 2013 that brokerage houses with ownership ties command $20-50 \%$ of the market share for bond issuances by affiliates [39]. Previous studies have shown that analysts who work for brokerage houses tend to give optimistic earnings estimates and investment opinions for corporations if they have related investment banking business $[2,6,8,19]$. Furthermore, Hong et al. [40] conclude that forecasting expertise results in better career opportunities but that brokerage houses also reward relatively optimistic analysts, suggesting that optimism is better for analysts' job security.

As Tables 7 and 8 show, the accuracy of the earnings estimates of brokers with ownership ties are not statistically different from those of analysts without ownership ties. In particular, we find a positive and highly significant impact of a capital market event on the AFE in Table 8. Overall, the findings suggest that brokerage houses provide optimistic earnings estimates for affiliates with which they have ownership ties, and this optimism is amplified during special events, such as debt financing. However, even brokerage houses with ownership ties stop presenting optimistic estimates when affiliates are about to announce equity financing, which signals a negative future operational environment, as the analysts also need to consider their reputational risk. Interestingly, brokers without ownership ties issue more pessimistic estimates during special periods, indicating that analysts without ownership ties interpret all external funding activities as negative signals about future earnings and try to issue more accurate estimates to maintain their reputations. Reputational risk increases during special periods because investors' attention is expected to increase. Additionally, we observe statistically significant optimism in the 30 days prior to events, but the significance is weaker in the 60 and 90 days prior to the events, implying that analysts issue optimistic estimates closer to events because analysts' recommendations influence investors in the short term. The accuracy of brokerage houses with ownership ties is not statistically different from that of other brokerage houses, suggesting that brokerage houses with ownership ties do not have superior information to that of brokerage houses without ownership ties or that the optimism of brokers with ownership ties reduces their accuracy even if they have superior information.

\subsection{Hypothesis 2}

Hypothesis 2 states that analysts issue pessimistic estimates during special periods.

Analysts' forecasts become pessimistic during special periods (statistically significant at the $1 \%$ level), as shown by the negative coefficient on the event dummy (FE) in Tables 5 and 6 . Considering that special periods are related to fundraising activities, analysts likely interpret these periods as negative signals for future earnings. Because managers are likely to prefer internal to external funding given a sufficient internal cashflow, pessimism is the logical behavior for analysts who wish to avoid reputational risk. Moreover, a company's management is likely to share more information when it needs funding from the financial market. Analysts without ownership ties likely reflect this information, including negative news, given investors' greater interest in a company that needs external funding, whereas analysts with ownership ties ignore this negative news [1,41]. 
Table 5. Differences in analyst forecast errors at affiliated vs. non-affiliated companies and during special vs. non-special periods.

\begin{tabular}{|c|c|c|c|c|c|c|c|}
\hline \multirow[b]{3}{*}{ Log(Trading value) } & \multicolumn{7}{|c|}{ Dependent Variable $=$ Forecast Error } \\
\hline & \multirow{2}{*}{$\begin{array}{c}\text { Base Model } \\
-1.331^{* * *} \\
(0.311)\end{array}$} & \multicolumn{2}{|c|}{ Model 1 = Event 30} & \multicolumn{2}{|c|}{ Model 2 = Event 60} & \multicolumn{2}{|c|}{ Model $3=$ Event 90} \\
\hline & & $\begin{array}{c}-1.052 * * * \\
(0.312)\end{array}$ & $\begin{array}{c}-1.036^{* * *} \\
(0.312)\end{array}$ & $\begin{array}{c}-1.137^{* * *} \\
(0.312)\end{array}$ & $\begin{array}{c}-1.114^{* * *} \\
(0.312)\end{array}$ & $\begin{array}{c}-1.351 * * * \\
(0.312)\end{array}$ & $\begin{array}{c}-1.296^{* * *} \\
(0.312)\end{array}$ \\
\hline Beta & $\begin{array}{c}8.290 * * * \\
(0.572)\end{array}$ & $\begin{array}{c}8.186^{* * *} \\
(0.572)\end{array}$ & $\begin{array}{c}8.176^{* * *} \\
(0.572)\end{array}$ & $\begin{array}{c}8.270 * * * \\
(0.572)\end{array}$ & $\begin{array}{c}8.213^{* * *} \\
(0.572)\end{array}$ & $\begin{array}{c}8.311 * * * \\
(0.572)\end{array}$ & $\begin{array}{c}8.152 * * * \\
(0.572)\end{array}$ \\
\hline Log(Market cap.) & $\begin{array}{c}-1.075^{* * *} \\
(0.281)\end{array}$ & $\begin{array}{c}-1.118^{* * * *} \\
(0.281)\end{array}$ & $\begin{array}{c}-1.123^{* * *} \\
(0.281)\end{array}$ & $\begin{array}{c}-1.073^{* * *} \\
(0.261)\end{array}$ & $\begin{array}{c}-1.079^{* * *} \\
(0.281)\end{array}$ & $\begin{array}{c}-1.048^{* * *} \\
(0.281)\end{array}$ & $\begin{array}{c}-1.017^{* * *} \\
(0.281)\end{array}$ \\
\hline Book-to-market & $\begin{array}{c}-0.061^{* * *} \\
(0.003)\end{array}$ & $\begin{array}{c}-0.058^{* * *} \\
(0.003)\end{array}$ & $\begin{array}{c}-0.058^{* * * *} \\
(0.003)\end{array}$ & $\begin{array}{c}-0.058^{* * *} \\
(0.003)\end{array}$ & $\begin{array}{c}-0.057^{* * * *} \\
(0.003)\end{array}$ & $\begin{array}{c}-0.061^{* * *} \\
(0.003)\end{array}$ & $\begin{array}{c}-0.059 * * * \\
(0.003)\end{array}$ \\
\hline Time difference & $\begin{array}{c}0.027^{* * *} \\
(0.001)\end{array}$ & $\begin{array}{c}0.027^{* * *} \\
(0.002)\end{array}$ & $\begin{array}{c}0.027^{* * *} \\
(0.002)\end{array}$ & $\begin{array}{c}0.027^{* * *} \\
(0.002)\end{array}$ & $\begin{array}{c}0.027^{* * *} \\
(0.002)\end{array}$ & $\begin{array}{c}0.027^{* * *} \\
(0.002)\end{array}$ & $\begin{array}{c}0.027^{* * *} \\
(0.002)\end{array}$ \\
\hline Company coverage & $\begin{array}{c}-0.050 * \\
(0.030)\end{array}$ & $\begin{array}{l}-0.048 \\
(0.030)\end{array}$ & $\begin{array}{l}-0.048 \\
(0.030)\end{array}$ & $\begin{array}{l}-0.048 \\
(0.030)\end{array}$ & $\begin{array}{l}-0.048 \\
(0.030)\end{array}$ & $\begin{array}{c}-0.052 * \\
(0.030)\end{array}$ & $\begin{array}{c}-0.056^{*} \\
(0.030)\end{array}$ \\
\hline Coverage & $\begin{array}{c}0.235^{* * *} \\
(0.048)\end{array}$ & $\begin{array}{c}0.234^{* * *} \\
(0.048)\end{array}$ & $\begin{array}{c}0.234^{* * *} \\
(0.048)\end{array}$ & $\begin{array}{c}0.231^{* * *} \\
(0.048)\end{array}$ & $\begin{array}{c}0.233^{* * *} \\
(0.048)\end{array}$ & $\begin{array}{c}0.230 * * * \\
(0.049)\end{array}$ & $\begin{array}{c}0.232 * * * \\
(0.048)\end{array}$ \\
\hline Earnings growth & $\begin{array}{c}-3.106^{* * *} \\
(0.328)\end{array}$ & $\begin{array}{c}-3.201^{* * *} \\
(0.328)\end{array}$ & $\begin{array}{c}-3.208^{* * *} \\
(0.328)\end{array}$ & $\begin{array}{c}-3.215 * * * \\
(0.328)\end{array}$ & $\begin{array}{c}-3.232 * * * \\
(0.328)\end{array}$ & $\begin{array}{c}-3.112 * * * \\
(0.328)\end{array}$ & $\begin{array}{c}-3.122 * * * \\
(0.328)\end{array}$ \\
\hline Log(Broker assets) & $\begin{array}{c}0.056 \\
(0.131)\end{array}$ & $\begin{array}{c}0.059 \\
(0.131)\end{array}$ & $\begin{array}{c}0.060 \\
(0.131)\end{array}$ & $\begin{array}{c}0.061 \\
(0.131)\end{array}$ & $\begin{array}{c}0.062 \\
(0.131)\end{array}$ & $\begin{array}{c}0.057 \\
(0.131)\end{array}$ & $\begin{array}{c}0.066 \\
(0.131)\end{array}$ \\
\hline BSI & $\begin{array}{c}0.423 * * * \\
(0.020)\end{array}$ & $\begin{array}{c}0.422 * * * \\
(0.020)\end{array}$ & $\begin{array}{c}0.423 * * * \\
(0.020)\end{array}$ & $\begin{array}{c}0.423 * * * \\
(0.020)\end{array}$ & $\begin{array}{c}0.425^{* * *} \\
(0.020)\end{array}$ & $\begin{array}{c}0.421 * * * \\
(0.020)\end{array}$ & $\begin{array}{c}0.429 * * * \\
(0.020)\end{array}$ \\
\hline IFRS & $\begin{array}{c}21.959^{* * *} \\
(0.423)\end{array}$ & $\begin{array}{c}21.929 * * * \\
(0.423)\end{array}$ & $\begin{array}{c}21.947^{* * *} \\
(0.123)\end{array}$ & $\begin{array}{c}21.939 * * * \\
(0.423)\end{array}$ & $\begin{array}{c}22.070^{* * * *} \\
(0.424)\end{array}$ & $\begin{array}{c}21.920^{* * *} \\
(0.423)\end{array}$ & $\begin{array}{c}22.279 * * * \\
(0.424)\end{array}$ \\
\hline Affiliate & $\begin{array}{c}8.118^{* * * *} \\
(1.463)\end{array}$ & & & & & & \\
\hline Event & & $\begin{array}{c}-6.698^{* * *} \\
(0.511)\end{array}$ & & $\begin{array}{c}-3.282 * * * \\
(0.422)\end{array}$ & & $\begin{array}{c}0.308 \\
(0.387)\end{array}$ & \\
\hline Debt financing & & & $\begin{array}{c}-6.586^{* * *} \\
(0.552)\end{array}$ & & $\begin{array}{c}-2.425^{* * *} \\
(0.455)\end{array}$ & & $\begin{array}{c}1.717^{* * *} \\
(0.407)\end{array}$ \\
\hline Equity financing & & & $\begin{array}{c}-8.500^{* * *} \\
(1.141)\end{array}$ & & $\begin{array}{c}-7.147^{* * *} \\
(0.874)\end{array}$ & & $\begin{array}{c}-7.233^{* * *} \\
(0.725)\end{array}$ \\
\hline Other transaction & & & $\begin{array}{c}-6.223 \\
(15.006)\end{array}$ & & $\begin{array}{l}-11.797 \\
(11.635)\end{array}$ & & $\begin{array}{c}-11.956 \\
(8.375)\end{array}$ \\
\hline No. of observations & 94,760 & 94,760 & 94,760 & 94,760 & 94,760 & 94,760 & 94,760 \\
\hline Adj. $\mathrm{R}^{2}$ & 0.091 & 0.093 & 0.093 & 0.092 & 0.092 & 0.091 & 0.092 \\
\hline
\end{tabular}

Note: This table shows the results of the baseline regressions. The sample includes 94,760 analyst report observations covering the period 2009-2013. Events 30,60, and 90 indicate that the event period is defined as 30,60, or 90 days, respectively, prior to the special period announcement. Here, Affiliate and Event are dummy variables that take a value of one if the analyst and the covered company are affiliated and if the analyst's report is published during the event period, respectively. We control for industry fixed effects using standard industry classifications. ${ }^{*}, * *$, and ${ }^{* * *}$ denote statistical significance at the $0.10,0.05$, and 0.01 levels, respectively. We present coefficient estimates from the regression models, with standard errors in parentheses.

Intuitively, pessimistic estimates during special periods should improve analysts' accuracy because fundraising activities signal an unfavorable future operational environment, and less optimistic estimates reduce FE. However, analysts' estimates become less accurate during event periods at the $1 \%$ significance level. One plausible reason is that analysts tend to make extreme corrections if they receive predictable new information [42], which likely encourages investor trading.

\subsection{Hypothesis 3}

Hypothesis 3 states that analysts with ownership ties issue optimistic estimates, even during special periods.

Analysts with ownership ties issue optimistic estimates during special periods, as shown in Table 6, whereas those without ownership ties announce pessimistic estimates. Presumably, investors focus more on companies that are about to announce fundraising activities because the internal cashflows of such companies' operations are insufficient to meet their cash outflows. As a result, the reputational risk to analysts increases during these periods. Accordingly, analysts without ownership ties issue 
pessimistic estimates because they interpret fundraising as a negative signal, as stated by the pecking order theory. However, analysts with ownership ties continue to provide optimistic estimates despite the reputational risk, although the lack of statistical significance makes it difficult to conclude that analysts with ownership ties become more optimistic. Thus, analysts with ownership ties seemingly believe that the benefits from supporting affiliates are larger than the losses to their reputations. Considering management changes and the close business relationships among affiliates, supporting management with optimistic estimates is likely to be better for an analyst's career. Furthermore, the accuracy of the estimates by analysts with ownership ties seems to increase during special periods; however, this result is not statistically significant.

Table 6. Joint effect of affiliates and special periods on analyst forecast errors.

\begin{tabular}{|c|c|c|c|c|c|c|}
\hline \multicolumn{7}{|c|}{ Panel A. Regression Analysis } \\
\hline & \multicolumn{6}{|c|}{ Dependent Variable $=$ Forecast Error } \\
\hline & \multicolumn{2}{|c|}{ Event $=$ Event 30} & \multicolumn{2}{|c|}{ Event $=$ Event 60} & \multicolumn{2}{|c|}{ Event $=$ Event 90} \\
\hline & Coefficient & Standard Error & Coefficient & Standard Error & Coefficient & Standard Error \\
\hline Log(Trading value) & $-1.055^{* * *}$ & 0.311 & $-1.139 * * *$ & 0.312 & $-1.354 * * *$ & 0.312 \\
\hline Beta & $8.167 * * *$ & 0.572 & $8.258 * * *$ & 0.572 & $8.298^{* * *}$ & 0.572 \\
\hline Log(Market cap.) & $-1.143^{* * *}$ & 0.281 & $-1.098^{* * *}$ & 0.281 & $-1.071^{* * *}$ & 0.281 \\
\hline Book-to-market & $-0.058 * * *$ & 0.003 & $-0.058^{* * *}$ & 0.003 & $-0.061^{* * *}$ & 0.003 \\
\hline Time difference & $0.027 * * *$ & 0.001 & $0.027^{* * *}$ & 0.002 & $0.027 * * *$ & 0.002 \\
\hline Company coverage & -0.046 & 0.030 & -0.047 & 0.030 & $-0.051 *$ & 0.296 \\
\hline Coverage & $0.239^{* * *}$ & 0.048 & $0.237^{* * *}$ & 0.048 & $0.235^{* * *}$ & 0.048 \\
\hline Earnings growth & $-3.180 * * *$ & 0.328 & $-3.200 * * *$ & 0.328 & $-3.097 * * *$ & 0.328 \\
\hline Log(Broker assets) & 0.060 & 0.131 & 0.060 & 0.131 & 0.057 & 0.131 \\
\hline BSI & $0.423 * * *$ & 0.020 & $0.424 * * *$ & 0.020 & $0.423^{* * *}$ & 0.020 \\
\hline IFRS & $21.958 * * *$ & 0.423 & $21.973 * * *$ & 0.423 & $21.953 * * *$ & 0.423 \\
\hline Affiliate & $6.916^{* * *}$ & 1.533 & $7.926^{* * *}$ & 1.599 & $7.594^{* * *}$ & 1.693 \\
\hline Event & $-6.830^{* * *}$ & 0.513 & $-3.296^{* * *}$ & 0.425 & 0.269 & 0.389 \\
\hline Affiliate $\times$ Event & $12.930 * *$ & 5.032 & 1.200 & 3.931 & 2.035 & 3.349 \\
\hline Industry fixed & \multicolumn{2}{|r|}{ Yes } & \multicolumn{2}{|c|}{ Yes } & \multicolumn{2}{|c|}{ Yes } \\
\hline No. of observations & \multicolumn{2}{|c|}{94,760} & \multicolumn{2}{|c|}{94,760} & \multicolumn{2}{|c|}{94,760} \\
\hline Adj. $\mathrm{R}^{2}$ & \multicolumn{2}{|r|}{0.093} & \multicolumn{2}{|c|}{0.092} & \multicolumn{2}{|c|}{0.091} \\
\hline
\end{tabular}

Note: This table presents the regression results for hypothesis 1 . The sample includes 94,760 analyst report observations covering the period 2009-2013. Events 30,60, and 90 indicate that the event period is defined as 30, 60, or 90 days, respectively, prior to the special period announcement. Here, Affiliate and Event are dummy variables that take a value of one if the analyst and the covered company are affiliated and if the analyst's report is published during the event period, respectively. We control for industry fixed effects using standard industry classifications. $*, * *$, and ${ }^{* * *}$ denote statistical significance at the $0.10,0.05$, and 0.01 levels, respectively. We present coefficient estimates from the regression models, with standard errors in parentheses.

Notably, analysts' optimism is statistically significant (at the 5\% level) 30 days prior to an event, but it is not statistically significant 60 and 90 days prior to an event. Thus, analysts with ownership ties issue optimistic estimates close to events because they try to influence investors more effectively. Barber et al. [9] and Kho and Kim [43] document that following the investment opinions of analysts generates positive returns only in the short term. This result supports our hypothesis that analysts with ownership ties issue especially optimistic estimates when affiliates need their support. 
Table 7. Differences in analyst forecast errors for affiliates vs. non-affiliated companies and during special vs. non-special periods.

\begin{tabular}{|c|c|c|c|c|c|c|c|}
\hline \multirow[b]{3}{*}{ Log(Trading value) } & \multicolumn{7}{|c|}{ Dependent Variable $=$ Absolute Forecast Error } \\
\hline & \multirow{2}{*}{$\begin{array}{c}\text { Base model } \\
3.678^{* * *} \\
(0.225)\end{array}$} & \multicolumn{2}{|c|}{ Model 1 = Event 30} & \multicolumn{2}{|c|}{ Model 2 = Event 60} & \multicolumn{2}{|c|}{ Model 3 = Event 90} \\
\hline & & $\begin{array}{c}3.529 * * * \\
(0.226)\end{array}$ & $\begin{array}{c}3.557 * * * \\
(0.226)\end{array}$ & $\begin{array}{c}3.444^{* * *} \\
(0.226)\end{array}$ & $\begin{array}{c}3.491 * * * \\
(0.226)\end{array}$ & $\begin{array}{c}3.272 * * * \\
(0.226)\end{array}$ & $\begin{array}{c}3.296^{* * *} \\
(0.226)\end{array}$ \\
\hline Beta & $\begin{array}{c}9.187^{* * *} \\
(0.415)\end{array}$ & $\begin{array}{c}9.251^{* * *} \\
(0.415)\end{array}$ & $\begin{array}{c}9.207^{* * *} \\
(0.414)\end{array}$ & $\begin{array}{c}9.227^{* * *} \\
(0.414)\end{array}$ & $\begin{array}{c}9.108^{* * *} \\
(0.414)\end{array}$ & $\begin{array}{c}9.352^{* * *} \\
(0.414)\end{array}$ & $\begin{array}{c}9.173^{* * *} \\
(0.413)\end{array}$ \\
\hline Log(Market cap.) & $\begin{array}{c}-2.947^{* * *} \\
(0.204)\end{array}$ & $\begin{array}{c}-2.090^{* * *} \\
(0.204)\end{array}$ & $\begin{array}{c}-2.934^{* * *} \\
(0.204)\end{array}$ & $\begin{array}{c}-2.917^{* * * *} \\
(0.204)\end{array}$ & $\begin{array}{c}-2.936^{* * *} \\
(0.203)\end{array}$ & $\begin{array}{c}-2.919 * * * \\
(0.203)\end{array}$ & $\begin{array}{c}-2.898^{* * *} \\
(0.203)\end{array}$ \\
\hline Book-to-market & $\begin{array}{c}0.104^{* * *} \\
(0.002)\end{array}$ & $\begin{array}{c}0.103^{* * *} \\
(0.002)\end{array}$ & $\begin{array}{c}0.104^{* * *} \\
(0.002)\end{array}$ & $\begin{array}{c}0.101 * * * \\
(0.002)\end{array}$ & $\begin{array}{c}0.103^{* * *} \\
(0.002)\end{array}$ & $\begin{array}{c}0.099 * * * \\
(0.002)\end{array}$ & $\begin{array}{c}0.100^{* * *} \\
(0.002)\end{array}$ \\
\hline Time difference & $\begin{array}{c}0.097^{* * *} \\
(0.001)\end{array}$ & $\begin{array}{c}0.097^{* * *} \\
(0.001)\end{array}$ & $\begin{array}{c}0.098^{* * *} \\
(0.001)\end{array}$ & $\begin{array}{c}0.098^{* * *} \\
(0.001)\end{array}$ & $\begin{array}{c}0.098^{* * *} \\
(0.001)\end{array}$ & $\begin{array}{c}0.098^{* * *} \\
(0.001)\end{array}$ & $\begin{array}{c}0.098^{* * *} \\
(0.001)\end{array}$ \\
\hline Company coverage & $\begin{array}{c}-0.687^{* * *} \\
(0.021)\end{array}$ & $\begin{array}{c}-0.689^{* * *} \\
(0.021)\end{array}$ & $\begin{array}{c}-0.687^{* * *} \\
(0.021)\end{array}$ & $\begin{array}{c}-0.691 \text { *** } \\
(0.021)\end{array}$ & $\begin{array}{c}-0.691 * * * \\
(0.021)\end{array}$ & $\begin{array}{c}-0.700 * * * \\
(0.021)\end{array}$ & $\begin{array}{c}-0.706^{* * *} \\
(0.021)\end{array}$ \\
\hline Coverage & $\begin{array}{c}0.149^{* * *} \\
(0.035)\end{array}$ & $\begin{array}{c}0.144^{* * *} \\
(0.035)\end{array}$ & $\begin{array}{c}0.146^{* * *} \\
(0.035)\end{array}$ & $\begin{array}{c}0.144^{* * *} \\
(0.035)\end{array}$ & $\begin{array}{c}0.147^{* * *} \\
(0.035)\end{array}$ & $\begin{array}{c}0.142^{* * *} \\
(0.035)\end{array}$ & $\begin{array}{c}0.146^{* * *} \\
(0.034)\end{array}$ \\
\hline Earnings growth & $\begin{array}{c}-12.987^{* * *} \\
(0.238)\end{array}$ & $\begin{array}{c}-12.944^{* * *} \\
(0.238)\end{array}$ & $\begin{array}{c}-12.960^{* * *} \\
(0.237)\end{array}$ & $\begin{array}{c}-12.871 \text { *** } \\
(0.238)\end{array}$ & $\begin{array}{c}-12.908^{* * *} \\
(0.237)\end{array}$ & $\begin{array}{c}-12.849^{* * *} \\
(0.237)\end{array}$ & $\begin{array}{c}-12.868^{* * *} \\
(0.237)\end{array}$ \\
\hline Log(Broker assets) & $\begin{array}{l}-0.079 \\
(0.095)\end{array}$ & $\begin{array}{l}-0.080 \\
(0.095)\end{array}$ & $\begin{array}{r}-0.080 \\
(0.095)\end{array}$ & $\begin{array}{l}-0.083 \\
(0.095)\end{array}$ & $\begin{array}{r}-0.080 \\
(0.095)\end{array}$ & $\begin{array}{l}-0.085 \\
(0.095)\end{array}$ & $\begin{array}{l}-0.075 \\
(0.095)\end{array}$ \\
\hline BSI & $\begin{array}{c}-0.173^{* * *} \\
(0.014)\end{array}$ & $\begin{array}{c}-0.173^{* * *} \\
(0.014)\end{array}$ & $\begin{array}{c}-0.170^{* * *} \\
(0.014)\end{array}$ & $\begin{array}{c}-0.175^{* * *} \\
(0.014)\end{array}$ & $\begin{array}{c}-0.171 * * * \\
(0.014)\end{array}$ & $\begin{array}{c}-0.179 * * * \\
(0.014)\end{array}$ & $\begin{array}{c}-0.172 * * * \\
(0.014)\end{array}$ \\
\hline IFRS & $\begin{array}{c}3.746^{* * *} \\
(0.307)\end{array}$ & $\begin{array}{c}3.742^{* * *} \\
(0.307)\end{array}$ & $\begin{array}{c}3.853^{* * *} \\
(0.307)\end{array}$ & $\begin{array}{c}3.727^{* * *} \\
(0.307)\end{array}$ & $\begin{array}{c}3.959 * * * \\
(0.307)\end{array}$ & $\begin{array}{c}3.665^{* * *} \\
(0.306)\end{array}$ & $\begin{array}{c}4.008^{* * *} \\
(0.307)\end{array}$ \\
\hline Affiliate & $\begin{array}{c}0.494 \\
(1.060)\end{array}$ & & & & & & \\
\hline Event & & $\begin{array}{c}3.634^{* * *} \\
(0.370)\end{array}$ & & $\begin{array}{c}4.010 * * * \\
(0.306)\end{array}$ & & $\begin{array}{c}5.572 * * * \\
(0.280)\end{array}$ & \\
\hline Debt financing & & & $\begin{array}{c}5.378^{* * *} \\
(0.400)\end{array}$ & & $\begin{array}{c}5.528^{* * *} \\
(0.329)\end{array}$ & & $\begin{array}{c}7.381^{* * *} \\
(0.294)\end{array}$ \\
\hline Equity financing & & & $\begin{array}{c}-3.438^{* * *} \\
(0.827)\end{array}$ & & $\begin{array}{c}-2.679 * * * \\
(0.632)\end{array}$ & & $\begin{array}{c}-1.388^{* * *} \\
(0.524)\end{array}$ \\
\hline Other transaction & & & $\begin{array}{c}-37.891 \text { *** } \\
(10.874)\end{array}$ & & $\begin{array}{c}-37.015^{* * *} \\
(8.421)\end{array}$ & & $\begin{array}{c}-36.701 \text { *** } \\
(6.052)\end{array}$ \\
\hline Industry fixed & Yes & & & & & & s \\
\hline $\mathrm{N}$ & 94,760 & 94,760 & 94,760 & 94,760 & 94,760 & 94,760 & 94,760 \\
\hline Adj. $R^{2}$ & 0.222 & 0.223 & 0.224 & 0.224 & 0.225 & 0.226 & 0.228 \\
\hline
\end{tabular}

Note: This table shows results for the baseline regressions. The sample includes 94,760 analyst report observations for the period 2009-2013. Events 30, 60, and 90 indicate that the event period is defined as 30, 60, or 90 days, respectively, prior to the special period announcement. Affiliate and Event are dummy variables that take a value of one if the analyst and the covered company are affiliated and if the analyst's report is published during the event period, respectively. Events 1,2, and 3 are dummy variables equal to one if the event is categorized as debt financing, equity financing, or other transactions, respectively. We control for industry fixed effects using standard industry classifications. ${ }^{*}, * *$, and ${ }^{* * *}$ denote statistical significance at the $0.10,0.05$, and 0.01 levels, respectively. We present the coefficient estimates from the regression models, with standard errors in parentheses.

Table 8. Joint effect of affiliates and special periods on analyst absolute forecast errors.

\begin{tabular}{|c|c|c|c|c|c|c|}
\hline & \multicolumn{6}{|c|}{ Dependent Variable $=$ Forecast Error } \\
\hline & \multicolumn{2}{|c|}{ Event $=$ Event 30} & \multicolumn{2}{|c|}{ Event $=$ Event 60} & \multicolumn{2}{|c|}{ Event $=$ Event 90} \\
\hline & Coefficient & Standard Error & Coefficient & Standard Error & Coefficient & Standard Error \\
\hline Log(Trading value) & $3.529 * * *$ & 0.226 & $3.446^{* * *}$ & 0.226 & $3.277 * * *$ & 0.226 \\
\hline Beta & $9.253^{* * *}$ & 0.415 & $9.225^{* * *}$ & 0.414 & $9.352 * * *$ & 0.414 \\
\hline Log(Market cap) & $-2.910 * * *$ & 0.204 & $-2.921 * * *$ & 0.204 & $-2.927 * * *$ & 0.203 \\
\hline Book-to-market & $0.103^{* * *}$ & 0.002 & $0.101^{* * *}$ & 0.002 & $0.099^{* * *}$ & 0.002 \\
\hline Time difference & $0.097^{* * *}$ & 0.001 & $0.098^{* * *}$ & 0.001 & $0.098^{* * *}$ & 0.001 \\
\hline Company coverage & $-0.689 * * *$ & 0.021 & $-0.691^{* * *}$ & 0.021 & $-0.701^{* * *}$ & 0.021 \\
\hline Coverage & $0.144^{* * *}$ & 0.035 & $0.144^{* * *}$ & 0.035 & $0.143^{* * *}$ & 0.035 \\
\hline Earnings growth & $-12.945^{* * *}$ & 0.238 & $-12.874^{* * *}$ & 0.238 & $-12.854^{* * *}$ & 0.237 \\
\hline Log(Broker assets) & -0.081 & 0.095 & -0.085 & 0.095 & -0.089 & 0.095 \\
\hline
\end{tabular}


Table 8. Cont.

\begin{tabular}{|c|c|c|c|c|c|c|}
\hline & \multicolumn{6}{|c|}{ Dependent Variable $=$ Forecast Error } \\
\hline & \multicolumn{2}{|c|}{ Event $=$ Event 30} & \multicolumn{2}{|c|}{ Event $=$ Event 60} & \multicolumn{2}{|c|}{ Event $=$ Event 90} \\
\hline & Coefficient & Standard Error & Coefficient & Standard Error & Coefficient & Standard Error \\
\hline BSI & $-0.173^{* * *}$ & 0.014 & $-0.174^{* * *}$ & 0.014 & $-0.179^{* * *}$ & 0.014 \\
\hline IFRS & $3.746^{* * *}$ & 0.307 & $3.732 * * *$ & 0.307 & $3.673^{* * *}$ & 0.306 \\
\hline Affiliate & 0.973 & 1.119 & 1.199 & 1.158 & 1.893 & 1.225 \\
\hline Event & $3.687^{* * *}$ & 0.372 & $4.058^{* * *}$ & 0.308 & $5.647^{* * *}$ & 0.282 \\
\hline Affiliate $\times$ Event & -5.133 & 3.650 & -4.324 & 2.848 & $-6.046^{* * *}$ & 2.423 \\
\hline Industry fixed effects & \multicolumn{2}{|c|}{ Yes } & \multicolumn{2}{|c|}{ Yes } & \multicolumn{2}{|c|}{ Yes } \\
\hline No. of observations & \multicolumn{2}{|c|}{94,760} & \multicolumn{2}{|c|}{94,760} & \multicolumn{2}{|c|}{94,760} \\
\hline Adj. $\mathrm{R}^{2}$ & \multicolumn{2}{|c|}{0.223} & \multicolumn{2}{|c|}{0.224} & \multicolumn{2}{|c|}{0.226} \\
\hline
\end{tabular}

Note: This table shows the regression results for hypothesis 1 . The sample includes 94,760 analyst report observations for the period 2009-2013. Events 30, 60, and 90 indicate that the event period is defined as 30, 60, or 90 days, respectively, prior to the special period announcement. Affiliate and Event are dummy variables taking a value of one if the analyst and the company under coverage are affiliated and if the analyst's report is published during the event period, respectively. We control for industry fixed effects using standard industry classifications. ${ }^{*}, * *$, and ${ }^{* * *}$ denote statistical significance at the $0.10,0.05$, and 0.01 levels, respectively. We present the coefficient estimates from the regression models, with standard errors in parentheses.

\subsection{Hypothesis 4}

Hypothesis 4 states that analysts with ownership ties issue pessimistic estimates during equity financing.

To further investigate the optimistic bias of analysts with ownership ties, we separate special periods into periods of debt financing, equity financing, and other equity transactions. In Table 9, the Event 1 dummy variable refers to debt financing, and the variables for Events 2 and 3 refer to equity financing and other equity transactions in Table 10, respectively.

Table 9. Joint effect of affiliates and special periods on analyst forecast errors with a detailed classification of special periods.

\begin{tabular}{|c|c|c|c|c|c|c|}
\hline & \multicolumn{6}{|c|}{ Dependent Variable $=$ Forecast Error } \\
\hline & \multicolumn{2}{|c|}{ Event $=$ Event 30} & \multicolumn{2}{|c|}{ Event $=$ Event 60} & \multicolumn{2}{|c|}{ Event $=$ Event 90} \\
\hline & Coefficient & Standard Error & Coefficient & Standard Error & Coefficient & Standard Error \\
\hline Log(Trading value) & $-1.035^{* * *}$ & 0.312 & $-1.116^{* * *}$ & 0.312 & $-1.299 * * *$ & 0.312 \\
\hline Beta & $8.160 * * *$ & 0.572 & $8.209^{* * *}$ & 0.572 & $8.144^{* * *}$ & 0.572 \\
\hline Log(Market cap) & $-1.151^{* * *}$ & 0.281 & $-1.107^{* * *}$ & 0.281 & $-1.043^{* * *}$ & 0.281 \\
\hline Book-to-market & $-0.058^{* * *}$ & 0.003 & $-0.058^{* * *}$ & 0.003 & $-0.059 * * *$ & 0.003 \\
\hline Time difference & $0.027^{* * *}$ & 0.002 & $0.027^{* * *}$ & 0.002 & $0.027^{* * *}$ & 0.002 \\
\hline Company coverage & -0.045 & 0.030 & -0.046 & 0.030 & -0.053 & 0.030 \\
\hline Coverage & $0.240^{* * *}$ & 0.048 & $0.239^{* * *}$ & 0.048 & $0.238^{* * *}$ & 0.048 \\
\hline Earnings growth & $-3.178^{* * *}$ & 0.328 & $-3.210^{* * *}$ & 0.328 & $-3.103^{* * *}$ & 0.328 \\
\hline Log(Broker assets) & 0.062 & 0.131 & 0.061 & 0.131 & 0.066 & 0.131 \\
\hline BSI & $0.424^{* * *}$ & 0.020 & $0.426^{* * *}$ & 0.020 & $0.430^{* * *}$ & 0.020 \\
\hline IFRS & $21.975^{* * *}$ & 0.423 & $22.103^{* * *}$ & 0.424 & $22.313^{* * *}$ & 0.424 \\
\hline Affiliate & $6.896^{* * *}$ & 1.533 & $7.932 * * *$ & 1.600 & $7.599^{* * *}$ & 1.685 \\
\hline Debt financing & $-6.768^{* * *}$ & 0.555 & $-2.465^{* * *}$ & 0.457 & $1.660^{* * *}$ & 0.409 \\
\hline Equity financing & -6.703 & 1.464 & $-7.054^{* * *}$ & 0.878 & $-7.246^{* * *}$ & 0.730 \\
\hline Other transaction & -6.703 & 15.911 & -13.243 & 12.494 & -13.543 & 9.016 \\
\hline Affiliate $\times$ Debt financing & $18.444^{* * *}$ & 5.545 & 3.927 & 4.354 & 4.447 & 3.746 \\
\hline $\begin{array}{c}\text { Affiliate } \times \text { Equity } \\
\text { financing }\end{array}$ & -9.730 & 11.411 & -8.906 & 8.163 & -1.972 & 5.762 \\
\hline $\begin{array}{l}\text { Affiliate } \times \text { Other } \\
\text { transaction }\end{array}$ & -2.139 & 47.732 & 3.350 & 34.222 & 4.260 & 24.289 \\
\hline Industry fixed & \multicolumn{2}{|r|}{ Yes } & \multicolumn{2}{|c|}{ Yes } & \multicolumn{2}{|r|}{ Yes } \\
\hline No. of observations & \multicolumn{2}{|r|}{94,760} & \multicolumn{2}{|c|}{94,760} & \multicolumn{2}{|r|}{94,760} \\
\hline Adj. $\mathrm{R}^{2}$ & \multicolumn{2}{|r|}{0.093} & \multicolumn{2}{|c|}{0.092} & \multicolumn{2}{|r|}{0.093} \\
\hline
\end{tabular}

Note: ${ }^{*} * *$ and ${ }^{* * *}$ denote statistical significance at the $0.10,0.05$, and 0.01 levels, respectively. 
Table 10. Comparison of forecast error across subsamples.

\begin{tabular}{|c|c|c|c|c|}
\hline \multirow[t]{3}{*}{ A. Event 1} & \multicolumn{4}{|c|}{ Dependent Variable $=$ Forecast Error $\&$ Event $=$ Event 1} \\
\hline & \multicolumn{2}{|c|}{$\begin{array}{l}\text { Affiliate \& Event } 1 \text { vs. } \\
\text { Affiliate \& Non-Event }\end{array}$} & \multicolumn{2}{|c|}{$\begin{array}{l}\text { Affiliate \& Event } 1 \text { vs. } \\
\text { Non-affiliate \& Event } 1\end{array}$} \\
\hline & F-Value & $p$-Value & F-Value & $p$-Value \\
\hline Event 30 & $4.43^{* *}$ & 0.035 & $22.41 * * *$ & $<0.0001$ \\
\hline Event 60 & 0.11 & 0.746 & $8.44^{* * *}$ & 0.004 \\
\hline Event 90 & 2.46 & 0.117 & $12.10^{* * *}$ & 0.0005 \\
\hline \multirow[t]{3}{*}{ B. Event 2} & \multicolumn{4}{|c|}{ Dependent Variable $=$ Forecast Error $\&$ Event $=$ Event 2} \\
\hline & \multicolumn{2}{|c|}{$\begin{array}{l}\text { Affiliate \& Event } 2 \text { vs. } \\
\text { Affiliate \& Non-Event }\end{array}$} & \multicolumn{2}{|c|}{$\begin{array}{l}\text { Affiliate \& Event } 2 \text { vs. } \\
\text { Non-affiliate \& Event } 2\end{array}$} \\
\hline & F-Value & $p$-Value & F-Value & $p$-Value \\
\hline Event 30 & 2.50 & 0.114 & 0.06 & 0.811 \\
\hline Event 60 & $3.78 *$ & 0.052 & 0.01 & 0.917 \\
\hline Event 90 & $2.82 *$ & 0.093 & 0.84 & 0.360 \\
\hline \multirow[t]{3}{*}{ C. Event 3} & \multicolumn{4}{|c|}{ Dependent Variable $=$ Forecast Error $\&$ Event $=$ Event 3} \\
\hline & \multicolumn{2}{|c|}{$\begin{array}{l}\text { Affiliate \& Event } 3 \text { vs. } \\
\text { Affiliate \& Non-Event }\end{array}$} & \multicolumn{2}{|c|}{$\begin{array}{l}\text { Affiliate \& Event } 1 \text { vs. } \\
\text { Non-affiliate \& Event } 3\end{array}$} \\
\hline & F-Value & $p$-Value & F-Value & $p$-Value \\
\hline Event 30 & 0.04 & 0.846 & 0.01 & 0.919 \\
\hline Event 60 & 0.09 & 0.759 & 0.11 & 0.740 \\
\hline Event 90 & 0.16 & 0.686 & 0.24 & 0.624 \\
\hline
\end{tabular}

The regression results for the interaction term are very interesting; analysts with ownership ties provide especially optimistic earnings estimates during debt financing periods. This result is only statistically significant for 30 days prior to an event and not for 60 or 90 days prior to the event. A plausible interpretation is that analysts with ownership ties issue optimistic estimates close to special periods to try to influence investors. However, even analysts with ownership ties stop providing optimistic estimates during equity financing periods. Given the lack of statistical significance for this result, we cannot conclude that analysts clearly become pessimistic. However, the result does indicate that even analysts with ownership ties are not optimistic when affiliates are about to announce equity financing. Affiliates may need support from analysts with ownership ties to obtain lower interest rates. Furthermore, analysts with ownership ties may see benefits to optimism (e.g., career or business opportunities) without a sizeable reputational risk because debt financing, in general, is a fairly regular corporate activity. However, listed companies do not typically use equity financing unless they are experiencing significant difficulties with debt financing. In this case, even ownership-tied analysts consider the reputational risk because equity financing is highly likely to signal a negative operational outlook.

Unsurprisingly, analysts without ownership ties issue pessimistic estimates before both debt financing and equity financing. Although sell-side analysts are well known for issuing optimistic estimates, analysts without ownership ties turn pessimistic when corporations need external funding because requiring funding is likely a negative signal for future operations and cashflows. Finally, the interaction term with the variable for equity transactions has coefficients in both directions with no statistical significance, suggesting that equity transactions do not materially affect analysts' estimates regardless of their ownership ties. None of the events significantly affect the accuracy of estimates by analysts with ownership ties. 


\section{Conclusions}

We demonstrate that brokerage houses with ownership ties provide optimistic earnings estimates for their ownership-tied affiliates, and this optimism is amplified during certain special periods, such as debt financing periods. However, even brokerage houses with ownership ties stop presenting optimistic estimates when their affiliates are about to announce equity financing, which signals a negative future operational environment, because the analysts need to consider the associated reputational risk. Interestingly, brokers without ownership ties issue especially pessimistic estimates during special periods, indicating that such analysts interpret all external funding activities as negative signals for future earnings and, thus, use accurate estimates to improve their reputations. The reputational risk increases during special periods because investors' attention increases. This optimism effect is statistically significant 30 days prior to an event, but is less significant 60 or 90 days prior to the event. This result implies that analysts issue optimistic estimates soon before events because their recommendations influence investors in the short term. The accuracy of brokerage houses with ownership ties is not statistically different from that of other brokerage houses, suggesting that either the former lack superior information or the optimism of brokers with ownership ties reduces their accuracy despite their superior information.

As noted above, this study contributes to the literature in three ways. First, whereas previous studies focus on the effects of business relationships, such as investment banking, on analyst estimates, we focus on ownership ties. Bae et al. [44] find that financial analysts are more likely to issue long-term forecasts for firms with more patent citations, and they find that financial analysts' long-term forecasts are more positive for firms with more patent citations. Given these results, they conclude that patent citations increase financial analysts' coverage and result in more positive forecasts for firms with impactful patents. Goh et al. [45] show that patent citations have more influence on future profitability than patent counts have and find that financial analysts pay more attention to firms with patent citations by showing greater followings for those firms. In addition, they find that analyst forecasts do not fully reflect the implications of the effect of patent citations on future earnings, and this undervaluation can mislead investors. Hence, they argue that financial analysts partially improve the information environment in terms of patent citations. More recently, Wang and Jiang [46] show that financial analysts may serve as an information bridge connecting brand equity and a firm's sustainable performance by providing professional recommendations for stock investments to public investors. Our findings further add to this broad literature on analysts' effects on firms and the market by highlighting affiliated analysts' manipulative decisions for affiliated firms' external financing. Second, we review all 3422 filings of companies in the sample to identify special periods, including periods of debt financing, equity financing, and other stake transactions, which previous studies have not done. In addition, although they are not reported in the text for brevity, we conduct several robustness tests by considering clustered standard errors at the analyst level, repeating the analyses for a different sample period, analyzing subsamples of the overall sample, and considering the difference in the FEs of affiliated and non-affiliated analysts. We find that the results are largely consistent with our main findings. They are available upon request. Lastly, we show that analysts interpret announcements of external funding as negative signals for future operations. In addition, analysts with ownership ties take minor reputational risks during debt financing periods, although they identify larger reputational risks during equity financing periods. This study is limited by not being able to distinguish clearly between the special relationship of ownership ties and business relationships because, in general, ownership ties result in close business relationships in Korea [47-50]. Additionally, the findings of this study should be interpreted with caution because some empirical results do not hold up over longer event periods. We attribute this result to the compounding effects following equity and debt financing. Hence, as we believe that our results are more pronounced over a shorter event period, further investigations of longer time horizons are a possible topic for future research. 
Author Contributions: E.L. and C.-G.P. designed and performed the research and analyzed the data. E.L. wrote the paper. C.Y.C. revised the paper. All authors read and approved the final manuscript.

Funding: This research received no external funding.

Conflicts of Interest: The authors declare no conflicts of interest.

\section{Appendix A}

Table A1. Description of data source.

\begin{tabular}{|c|c|c|}
\hline Variable & Definition & Data Source \\
\hline \multicolumn{3}{|c|}{ Company-specific variables } \\
\hline Book-to-market ratio & $\begin{array}{l}\text { Company's net equity over market capitalization at fiscal } \\
\text { year end }\end{array}$ & KISVALUE \\
\hline Beta & Company's market beta for the previous three years & KISVALUE \\
\hline Market cap. & $\begin{array}{l}\text { Natural logarithm of the company's market } \\
\text { capitalization at year end in Korean won }\end{array}$ & KISVALUE \\
\hline Trading value & $\begin{array}{l}\text { Natural logarithm of the average daily trading value of } \\
\text { the company in Korean won }\end{array}$ & KISVALUE \\
\hline Number of analysts & The number of analysts who cover the company & KISVALUE \\
\hline BSI & Manufacturing Business Survey Index & Bank of Korea \\
\hline Net income growth & $\begin{array}{l}\text { Dummy variable equal to one if the net income for the } \\
\text { controlling stake exhibits growth and zero otherwise }\end{array}$ & KISVALUE \\
\hline \multicolumn{3}{|c|}{ Analyst/analyst report-specific variables } \\
\hline Coverage & The number of companies under coverage for the analyst & KISVALUE \\
\hline Time difference & $\begin{array}{l}\text { analyst's report and the publication date of the actual } \\
\text { financial statement }\end{array}$ & KISVALUE \\
\hline Asset size of brokers & $\begin{array}{l}\text { Natural logarithm of the total asset size of the brokerage } \\
\text { house in Korean won }\end{array}$ & KISVALUE \\
\hline \multicolumn{3}{|c|}{ Main variables of interest } \\
\hline IFRS & $\begin{array}{l}\text { Dummy variable equal to one if the company adopts } \\
\text { K-IFRS for the fiscal year in which an analyst publishes a } \\
\text { report and zero otherwise }\end{array}$ & DART \\
\hline Affiliate & $\begin{array}{l}\text { Dummy variable equal to one if the covered company } \\
\text { and the analyst are affiliated and zero otherwise }\end{array}$ & KISVALUE \\
\hline Event & $\begin{array}{l}\text { Dummy variable, equal to one if the analyst report is } \\
\text { published during the special period, where the event } \\
\text { period is defined as } 30,60 \text {, or } 90 \text { days prior to the } \\
\text { announcement of the special period. Event } 1 \text { indicates } \\
\text { debt financing activities, Event } 2 \text { indicates equity } \\
\text { financing activities, and Event } 3 \text { indicates other relevant } \\
\text { filings. See Table } 5 \text { for details on each category. }\end{array}$ & DART \\
\hline
\end{tabular}

\section{References}

1. McNichols, M.; O’Brien, P.C. Self-Selection and analyst coverage. J. Account. Res. 1997, 35, 167-199. [CrossRef]

2. Michaely, R.; Womack, K. Conflict of interest and the credibility of underwriter analyst recommendations. Rev. Financ. Stud. 1999, 12, 653-686. [CrossRef]

3. Choi, D.; Choi, P.M.S.; Choi, J.H.; Chung, C.Y. Does sustainable corporate governance enhance accounting practice? Evidence from the Korean market. Sustainability 2020, 12, 2585. [CrossRef]

4. Park, C.K.; Youn, T.H. Conflict of interests and analysts' forecast. KDI EWC Ser. Econ. Policy 2009, 31, $239-276$.

5. Li, W.Y.; Shin, H.H.; Chang, J.H. A study on analysts' conflict of interests. Korean Account. Assoc. 2005, 30, 173-194.

6. Jackson, A. Trade generation, reputation, and sell-side analysts. J. Financ. 2005, 60, 673-717. [CrossRef] 
7. Fang, L.; Yasuda, L. The effectiveness of reputation as a disciplinary mechanism in sell-side research. Rev. Financ. Stud. 2009, 22, 3735-3777. [CrossRef]

8. Dugar, A.; Nathan, S. The effect of investment banking relationships on financial analysts' earnings forecasts and investment recommendations. Contemp. Account. Res. 1995, 12, 131-160. [CrossRef]

9. Barber, B.M.; Lehavy, R.; Trueman, B. Can investors profit from the prophets? Security analyst recommendations and stock returns. J. Financ. 2001, 56, 531-565. [CrossRef]

10. Stickel, S. Reputation and performance among security analysts. J. Financ. 1992, 47, 1811-1836. [CrossRef]

11. Womack, L.K. Do brokerage analysts' recommendations have investment value? J. Financ. 1996, 51, $137-167$. [CrossRef]

12. Chen, S.; Matsumoto, D. Favorable versus unfavorable recommendations: The impact on analyst access to management-provided information. J. Account. Res. 2006, 44, 657-689. [CrossRef]

13. Das, S.; Levine, C.B.; Sivaramakrishnan, K. Earnings predictability and bias in analysts' earnings forecasts. Account. Rev. 1998, 73, 277-294.

14. Francis, J.; Hanna, D.; Philbrick, D. Management communications with securities analysts. J. Account. Econ. 1997, 24, 363-394. [CrossRef]

15. Ke, B.; Yu, Y. The effect of issuing biased earnings forecasts on analysts' access to management and survival. J. Account. Res. 2006, 44, 965-999. [CrossRef]

16. Lim, T. Rationality and analysts' forecast bias. J. Financ. 2001, 56, 369-385. [CrossRef]

17. Jegadeesh, N.; Kim, J.; Krische, S.; Charles, M.; Lee, C. Analyzing the analysts: When do recommendations add value? J. Financ. 2004, 59, 1083-1124. [CrossRef]

18. Eccles, R.; Crane, D. Doing Deals: Investment Banks at Work; Harvard Business School Press: Boston, MA, USA, 1988.

19. Lin, H.; McNichols, M. Underwriting relationships, analysts' earnings forecasts and investment recommendations. J. Account. Econ. 1998, 25, 101-127. [CrossRef]

20. Meng, X. Analyst reputation, communication, and information acquisition. J. Account. Res. 2015, 53, $119-173$. [CrossRef]

21. Chen, Q.; Francis, J.; Jiang, W. Investor learning about analyst predictive ability. J. Account. Econ. 2005, 39, 3-24. [CrossRef]

22. Groysberg, B.; Healy, P.M.; Maber, D. What drives sell-side analyst compensation at high-status banks? J. Account. Res. 2011, 49, 969-1000. [CrossRef]

23. Brav, A.; Lehavy, R. An empirical analysis of analysts' target prices: Short-Term informativeness and long-term dynamics. J. Financ. 2003, 58, 1933-1967. [CrossRef]

24. Ko, K.J.; Huang, Z.J. Arrogance can be a virtue: Overconfidence, information acquisition, and market efficiency. J. Financ. Econ. 2007, 84, 529-560. [CrossRef]

25. Kwak, B.; Mo, K. Group-Affiliated analysts' strategic forecasts during a year: Evidence from Korea. Emerg. Mark. Financ. Trade 2019, 55, 59-77. [CrossRef]

26. Lim, Y.; Kim, H. Market reaction to optimistic bias in the recommendations of chaebol-affiliated analysts. J. Contemp. Account. Econ. 2019, 15, 224-242. [CrossRef]

27. Myers, S.C.; Majluf, N.S. Corporate financing and investment decisions when firms have information that investors do not have. J. Financ. Econ. 1984, 13, 187-221. [CrossRef]

28. Rangan, S. Earnings before seasoned equity offerings: Are they overstated? J. Financ. Econ. 1998, 50, 101-122. [CrossRef]

29. Shivakumar, L. Do firms mislead investors by overstating earnings before seasoned equity offering? J. Account. Econ. 2000, 29, 339-371. [CrossRef]

30. Schipper, K. Analysts' forecasts. Account. Horiz. 1991, 5, 105.

31. Lo, H.C. Do firm size influence financial analyst research reports and subsequent stock performance. Account. Financ. Res. 2017, 6, 181-196. [CrossRef]

32. Yu, F. Analyst coverage and earnings management. J. Financ. Econ. 2008, 88, 245-271. [CrossRef]

33. Clement, M.B. Analyst forecast accuracy: Do ability, resources, and portfolio complexity matter? J. Account. Econ. 1999, 21, 285-303. [CrossRef]

34. Clement, M.B.; Tse, S.Y. Financial analyst characteristics and herding behavior in forecasting. J. Financ. 2005, 60, 307-341. [CrossRef] 
35. Jacob, J.; Lys, T.Z.; Neale, M.A. Expertise in forecasting performance of security analysts. J. Account. Econ. 1999, 28, 51-82. [CrossRef]

36. Oh, W.J.; Park, K.J. Impact from characteristic of brokerage house on analysts' estimate. Korean Acad. Soc. Account. 2007, 27, 1-24.

37. Lee, E.; Park, C.G. Does adoption of K-IFRS increase upward bias in analysts' earnings forecasts? Korean J. Financ. Manag. 2019, 36, 179-205.

38. Bradshaw, M. The use of target prices to justify sell-side analysts stock recommendations. Account. Horiz. 2002, 16, 27-41. [CrossRef]

39. Lang, L.H.; Litzenberger, R.H. Dividend announcements: Cash flow signalling vs. free cash flow hypothesis? J. Financ. Econ. 1989, 24, 181-191. [CrossRef]

40. Hong, H.; Kubik, J.D.; Solomon, A. Security analysts' career concerns and herding of earnings forecasts. Rand J. Econ. 2000, 31, 121-144. [CrossRef]

41. Eastwood, J.C.; Nutt, S.R. Inefficiency in analysts' earnings forecasts: Systematic misreaction or systematic optimism? J. Financ. 1999, 54, 1777-1797. [CrossRef]

42. De Bondt, W.F.M.; Thaler, R.M. Do security analysts overreact? Am. Econ. Rev. 1990, 80, 52-57.

43. Kho, B.; Kim, J. Earnings forecast accuracy and recommendation profitability of the analyst in Korea. Asia Pac. J. Financ. Stud. 2007, 36, 1009-1047.

44. Bae, J.; Hur, W.; Lee, J.; Goh, J. Patent citations and financial analysts' long-term growth forecasts. Sustainability 2017, 9, 846. [CrossRef]

45. Goh, J.; Lee, J.; Hur, W.; Ju, Y. Do analysts fully reflect information in patents about future earnings? Sustainability 2019, 11, 2869. [CrossRef]

46. Wang, K.; Jiang, W. Brand equity and firm sustainable performance: The mediating role of analysts' recommendations. Sustainability 2019, 11, 1086. [CrossRef]

47. Liu, C.; Chung, C.Y.; Sul, H.K.; Wang, K. Does hometown advantage matter? The case of institutional blockholder monitoring on earnings management in Korea. J. Int. Bus. Stud. 2018, 49, 196-221. [CrossRef]

48. Choi, P.M.S.; Chung, C.Y.; Hwang, J.H.; Liu, C. Heads I Win, Tails You Lose: Institutional Monitoring Of Executive Pay Rigidity. J. Financ. Res. 2019, 42, 789-816. [CrossRef]

49. Choi, P.M.S.; Chung, C.Y.; Liu, C. Self-attribution of overconfident CEOs and asymmetric investment-cash flow sensitivity. N. Am. J. Econ. Financ. 2018, 46, 1-14. [CrossRef]

50. Chung, C.Y.; Hur, S.K.; Liu, C. Institutional investors and cost stickiness: Theory and evidence. N. Am. J. Econ. Financ. 2019, 47, 336-350. [CrossRef] 